\title{
Crohn's disease in the upper gastrointestinal tract. Own experience and review of the literature
}

\author{
Choroba Leśniowskiego-Crohna w górnej części przewodu pokarmowego. \\ Doświadczenia własne i przegląd piśmiennictwa
}

\author{
Małgorzata Reszczyńska, Elżbieta Poniewierka, Dorota Waśko-Czopnik, Leszek Paradowski \\ Department of Gastroenterology and Hepatology, Medical University of Wroclaw, Poland
}

Przegląd Gastroenterologiczny 2011; 6 (1): 23-29

DOI: 10.5114/pg.2011.20104

Key words: Crohn's disease, extra-intestinal manifestation, biological treatment.

Słowa kluczowe: choroba Leśniowskiego-Crohna, manifestacje pozajelitowe, leczenie biologiczne.

Address for correspondence: Małgorzata Reszczyńska, MD, Department of Gastroenterology and Hepatology, Medical University of Wroclaw, ul. Borowska 213, 50-556 Wrocław, tel. +48 7173321 20, fax +48 7173321 29, e-mail: g.reszczynska@gmail.com

\begin{abstract}
Introduction: Crohn's disease (CD) is an inflammatory bowe disease. The most common location of CD is the ileo-colonic region, although it can affect any part of the gastrointestinal tract.

Aim: To present and analyse the cases of upper digestive tract CD manifestation in the material of the Department of Gastroenterology and Hepatology, Medical University of Wroclaw. Material and methods: In our Department of Gastroenterology and Hepatology, Medical University of Wroclaw, from January 2001 to July 2010 we hospitalized 686 patients with diagnosed CD. We identified patients by a search of our database which includes the ICD-10 diagnoses of 686 patients with CD. Medical records of all cases with upper Gl involvement were reviewed and an analysis was performed.

Results: The diagnosis of upper Gl involvement of CD was established in 7 patients. Among the 7 subjects with $C D$ in the upper digestive tract were 4 women and 3 men. In 4 cases lesions were found in the oral cavity, in 2 in the oesophagus, in 4 in the stomach, and in 2 in the duodenum.

Conclusions: The diagnosis of CD should be taken into consideration for every patient with chronic inflammatory lesions, particularly in the oral cavity. Clinicians should consider the necessity of upper endoscopy evaluation for every patient with CD.
\end{abstract}

\section{Introduction}

Crohn's disease (CD) is an inflammatory bowel disease. The inflammation in CD is transmural, mostly granulomatous, originally described as an inflammatory lesion

\section{Streszczenie}

Wstęp: Choroba Leśniowskiego-Crohna (Crohn's disease - CD) jest chorobą zapalną jelit. Najczęstszą lokalizacją zmian w CD jest okolica krętniczo-kątnicza, jednak mogą one występować w każdej części przewodu pokarmowego.

Cel: Przedstawienie i analiza przypadków CD w zakresie górnej części przewodu pokarmowego w materiale Klinki Gastroenterologii i Hepatologii Akademii Medycznej we Wrocławiu.

Materiat i metody: W Klinice Gastroenterologii i Hepatologii w okresie od stycznia 2001 r. do lipca 2010 r. hospitalizowano 668 pacjentów z rozpoznaniem choroby Leśniowskiego-Crohna. Pacjentów z CD wyłoniono, przeszukując dane w bazie pacjentów na podstawie kodu choroby według ICD-10. Przeanalizowano historie chorób wszystkich pacjentów z zajęciem górnej części przewodu pokarmowego.

Wyniki: Rozpoznanie CD z lokalizacją w górnym odcinku przewodu pokarmowego ustalono w 7 przypadkach. Wśród wspomnianych pacjentów były 4 kobiety i 3 mężczyzn. W czterech przypadkach zmiany stwierdzono $w$ jamie ustnej, w dwóch w przełyku, w czterech w żołądku oraz w dwóch w dwunastnicy. Wnioski: Rozpoznanie CD powinno być brane pod uwagę u każdego pacjenta z przewlekłymi zmianami zapalnymi, szczególnie w jamie ustnej. Klinicyści powinni rozważyć wykonywanie badań endoskopowych górnego odcinka przewodu pokarmowego u każdego pacjenta z rozpoznaniem choroby Leśniowskiego-Crohna.

of the small intestine [1], although it can affect any site of the gastrointestinal tract from the mouth to the anus [2]. The most common location of $C D$ is the ileo-colonic region. It is rare to observe accompanying lesions in the 
Table I. Gastrointestinal location of Crohn's disease

Tabela I. Lokalizacja zmian w chorobie Leśniowskiego-Crohna w przewodzie pokarmowym

\begin{tabular}{|c|c|c|c|c|c|c|c|c|}
\hline & \multirow[t]{2}{*}{ Sex } & \multirow{2}{*}{$\begin{array}{c}\text { Age } \\
\text { at diagnosis }\end{array}$} & \multicolumn{6}{|c|}{ Location of lesion } \\
\hline & & & Oral cavity & Oesophagus & Stomach & Duodenum & Small intestine & Large intestine \\
\hline 1. & M & 27 & + & + & - & - & + & + \\
\hline 2. & M & 14 & - & - & - & + & + & + \\
\hline 3. & $\mathrm{~F}$ & 34 & - & + & + & - & + & + \\
\hline 4. & $\mathrm{~F}$ & 53 & + & - & - & - & + & + \\
\hline 5. & $\mathrm{~F}$ & 24 & + & - & + & - & + & + \\
\hline 6. & $M$ & 29 & + & - & + & - & + & - \\
\hline 7. & $\mathrm{~F}$ & 35 & - & - & + & + & + & + \\
\hline
\end{tabular}

Table II. Relation in years between first appearance of lesions in the upper gastrointestinal tract and establishment of the diagnosis of CD Tabela II. Zależność w latach pomiędzy stwierdzeniem zmian $w$ górnym odcinku przewodu pokarmowego a postawieniem rozpoznania $C D$

\begin{tabular}{ccccc} 
& \multirow{2}{*}{$\begin{array}{c}\text { Age } \\
\text { at CD } \\
\text { diagnosis }\end{array}$} & \multicolumn{4}{c}{$\begin{array}{c}\text { Time of upper gastrointestinal } \\
\text { involvement appearance }\end{array}$} \\
\cline { 3 - 6 } & & $\begin{array}{c}\text { Before the final } \\
\text { CD diagnosis } \\
\text { was established }\end{array}$ & $\begin{array}{c}\text { At the time of } \\
\text { CD diagnosis }\end{array}$ & $\begin{array}{c}\text { After the } \\
\text { CD diagnosis }\end{array}$ \\
\hline 1. & 27 & + & + & - \\
\hline 2. & 14 & - & - & $+(4$ years $)$ \\
\hline 3. & 34 & - & - & $+(1$ year $)$ \\
\hline 4. & 53 & + & - & - \\
\hline 5. & 24 & - & - & $+(5$ years $)$ \\
\hline 6. & 29 & - & - & $+(9$ years $)$ \\
\hline 7. & 35 & - & - & $+(4$ years $)$
\end{tabular}

upper gastrointestinal tract. Isolated forms of this manifestation are seen very rarely [2]. However, sometimes symptoms related to the manifestation of the disease in the proximal gastrointestinal tract may dominate the clinical presentation, which leads to an average delay in establishing the diagnosis of about 13-18 months [3]. The presence of inflammatory lesions in the perianal region is related to higher risk of extra-intestinal manifestations [4]. There are a lot of data in the literature indicating that the oral cavity can be the site of first manifestation of CD, which can precede or coexist with the colon manifestation of the disease [5-7]. According to the literature from recent years, those lesions are relatively often observed among patients with already diagnosed CD [7].

The aim of this study is to present and analyse the cases of $C D$ with upper gastrointestinal tract involvement in the material of the Department of Gastroenterology and Hepatology, Medical University of Wroclaw.

\section{Material and methods}

We identified patients by a search of our database which includes the ICD-10 diagnoses of 686 patients with CD, hospitalized in our Department of Gastroenterology and Hepatology, Medical University of Wroclaw, from January 2001 to July 2010. Medical records of all cases with upper Gl involvement were reviewed and the analysis was made. We identified 7 patients with the diagnosis of CD in the upper gastrointestinal tract, which is $1.04 \%$ of the total hospitalizations due to CD. According to the literature, the appearance of CD in the upper gastrointestinal tract is at the level of $0.5-13 \%[8,9]$.

\section{Results}

Among 7 subjects with CD in the upper digestive tract were 4 women and 3 men. In 4 cases the lesions were found in the oral cavity, in 2 in the oesophagus, in 4 in the stomach, and in 2 in the duodenum.

In 1 patient with oral cavity lesions, the oral cavity was the only location of CD except for the intestine. In other cases the lesions were also located in the oesophagus or stomach. CD lesions were observed in the small intestine in all patients.

The youngest patient was 14, the oldest 53 years at the time of the diagnosis. Both the age of the patients at the time of the diagnosis of CD and the location of the lesions are illustrated in table I.

The relation between the first appearance of lesions in the upper gastrointestinal tract and the establishment of the diagnosis of CD is illustrated in table II. The duration of $C D$ in years at the time of diagnosis of upper gastrointestinal manifestation was different in each case.

In 2 cases, patients reported periodic appearance of the lesions in the oral cavity years before the final diagnosis of CD was established (cases 1 and 4). In the first case, at the time of diagnosis, the first symptoms, such as a few months history of mouth pain and difficulty in swallowing, bleeding from the lower gastrointestinal 
tract and diarrhoea, were related to both the oesophageal and intestinal manifestation of the disease. In the other cases the upper digestive tract involvement appeared years after the diagnosis of $C D$ was made $(4,1,5,9$ and 4 years respectively).

\section{Endoscopic appearance of the lesions Oral cavity}

According to obtained data, the presence of the lesions in the oral cavity was related to exacerbation of CD. In 2 cases (cases 1,4 ) the lesions were present a few years before the final diagnosis of CD was established. The lesions were characterized as aphthous type recurrent ulcerations in all cases with oedema, rubor and pain, mostly located on the gingival mucosa and in 1 case on the frenulum. In the fourth case the ulcerations were described as superficial, linear ulcers, situated in the mucous membrane of the cheeks, lips or on the tongue (fig. 1), always associated with exacerbation of the disease. The intensification of $C D$ treatment was effective therapy for those changes in the oral mucosa.

\section{Oesophagus}

Two subjects presented lesions in the oesophagus. In the first case endoscopic examination of the upper digestive tract revealed numerous linear, flat erosions in the whole oesophagus (fig. 2) with contact bleeding of the mucosa during endoscopic manipulation. In the other case (case 3), endoscopy of the upper digestive tract revealed linear erosions in the middle part of the oesophagus in a $10 \mathrm{~cm}$ long section (fig. 3).

\section{Stomach}

In 4 cases lesions of CD were found in the stomach. In 2 cases (cases 6, 7) lesions were characterized as irregular ulceration of the pylorus, narrowing the pylorus lumen (fig. 4). Erosions and aphthous type ulcerations of the prepyloric region of the stomach were found in 1 case (case 5). Also in 1 subject (case 3 ) pseudopolyps were found both in the subcardial region and in the proximal part of the stomach body. In this subject subsequent endoscopy, performed 4 years later (during remission of the disease), revealed cobblestone appearance of the mucosa (fig. 5). In all cases inflammation of the stomach mucosa was diagnosed.

\section{Duodenum}

Duodenal location of the CD lesions was observed in 2 cases. In the first subject (case 2 ) the described lesion was a linear ulceration, located in the distal part of the duodenum, and in subsequent endoscopy 2 years later,

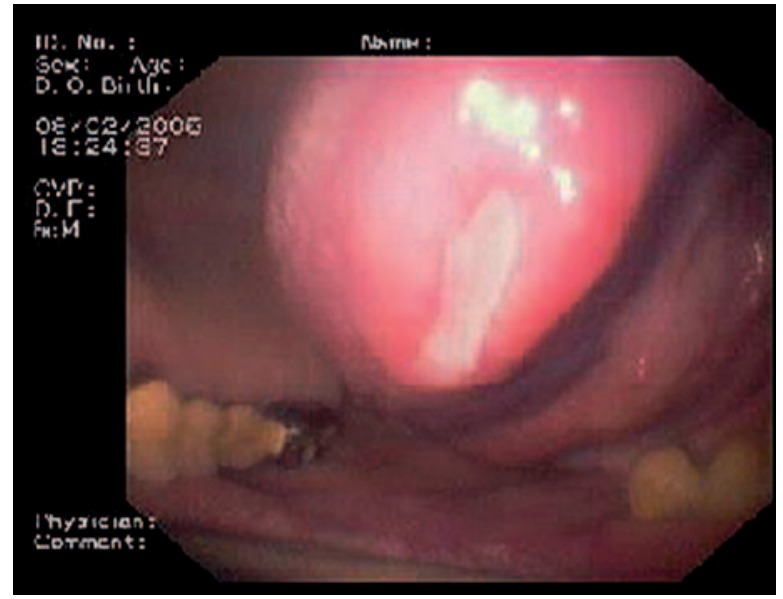

Fig. 1. Ulceration of the tongue

Ryc. 1. Owrzodzenie na języku

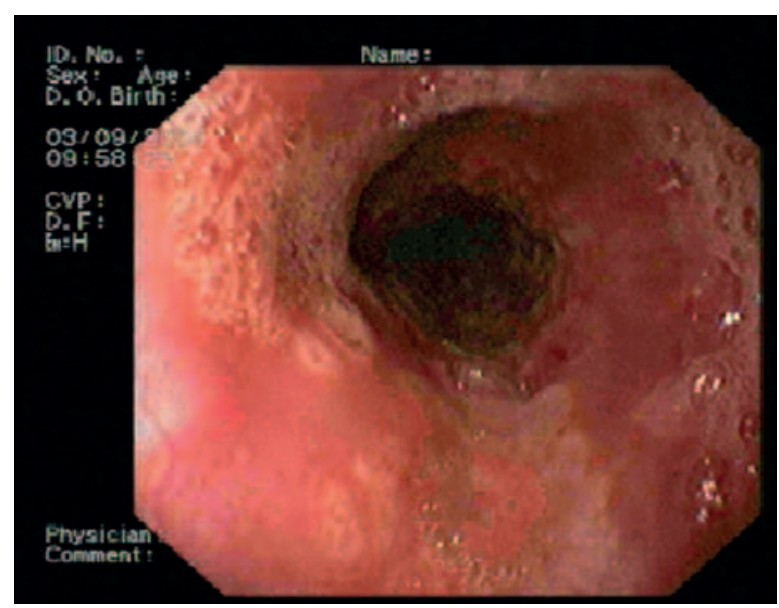

Fig. 2. Flat erosions in the oesophagus

Ryc. 2. Płaskie nadżerki w przetyku

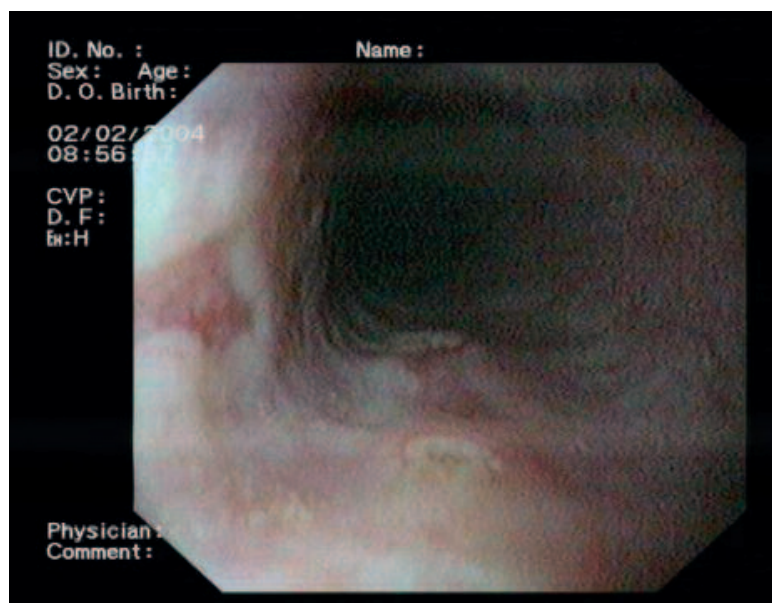

Fig. 3. Linear erosions in the middle part of the oesophagus

Ryc. 3. Linijne nadżerki w środkowej części przetyku 


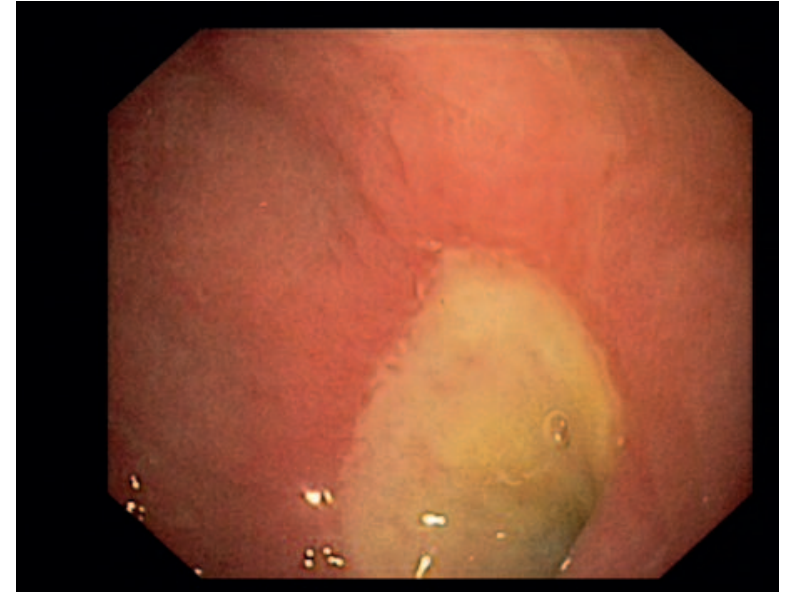

Fig. 4. Ulceration of the pylorus, narrowing the lumen

Ryc. 4. Owrzodzenie odźwiernika zwężające jego światło

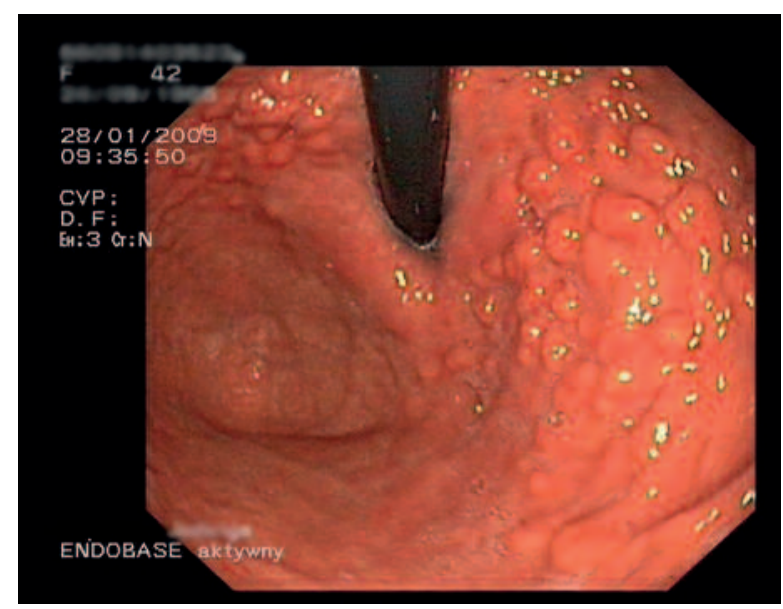

Fig. 5. Cobblestone appearance of the gastric mucosa

Ryc. 5. Obraz brukowania błony śluzowej żołądka

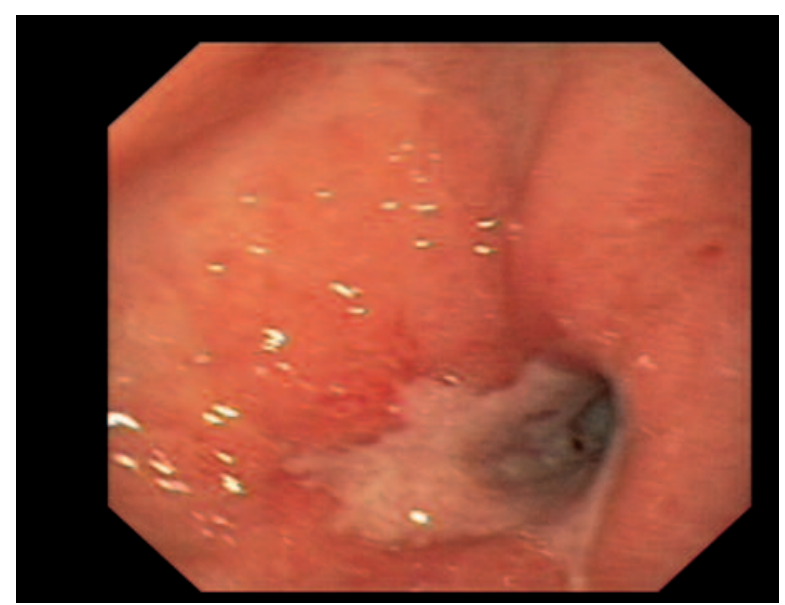

Fig. 6. Ulceration in the duodenum

Ryc. 6. Owrzodzenie w dwunastnicy in this location stricture of the duodenum was described. In the second case (case 7) ulceration of the duodenal bulb region with associated extra-bulb stricture was revealed. Also, smaller ulcerations were present in the distal part of the duodenum (fig. 6).

\section{Histopathological evaluation}

In spite of several histological examinations of specimens obtained from oral, oesophageal, stomach and duodenal lesions, no histological features specific for CD were found. In the cases of oral cavity lesions only in 1 subject (case 4) was the specimen obtained from ulceration on the tongue; however, no specific features for CD were found. The histopathological examination of the biopsy specimen from the oesophagus revealed small granulocyte clusters in 1 case and inflammation in the second. In the specimens of the stomach the histological diagnosis in all cases was active inflammation of the mucosa and in subjects with duodenal manifestation the histopathological evaluation revealed chronic enteritis.

\section{Treatment and follow-up}

The treatment of CD lesions in the upper gastrointestinal tract was based on conventional medications. All patients with lesions in the stomach or duodenum underwent proton pump inhibitor (PPI) therapy (administration of PPI in this condition is controversial and according to the literature it does not have a theoretical basis). Prior to the therapy, infection by Helicobacter pylori (H. pylori) was ruled out in each case. In the majority of cases withdrawal of symptoms from the upper digestive tract appeared with intensified treatment of the basic condition (administration of PPI, systemic corticosteroids).

Five of 7 cases underwent biological therapy. In the first and sixth case adalimumab was used (1 case induction therapy with a dose of $80 \mathrm{mg}$ at week 0 followed by a $40 \mathrm{mg}$ dose every 2 weeks, for a total of 8 doses; $6^{\text {th }}$ case - a clinical trial with 24 months history of adalimumab administration). In the other cases infliximab was administered. The indications for implementation of biological treatment were complex. In all cases the course of the disease was severe and progressive, and patients underwent numerous surgical interventions with partial resection of the small intestine in 2 subjects (cases 4, 5), hemicolectomy in 1 case (case 4) and partial resection of the large intestine in 1 case (case 2). The biological treatment was interrupted in 2 cases, due to the appearance of pyoderma gangrenosum as a side effect of the therapy (case 2) and to financial problems with access to medication (case 4). The 
third subject underwent biological therapy (infliximab) for 12 months, resulting in remission of the disease for 4 years. Remission was also achieved in the first case after the administration of the 8 doses of adalimumab. There was no success with the biological treatment (adalimumab) in the second case. The therapy lasted for 24 months (clinical trial). The trial was undertaken years before the disclosure of $C D$ lesions in the stomach. The course of the disease in this case is still severe.

In 1 subject the biological therapy was undertaken prior to the appearance of upper digestive tract lesions, and in the rest of the cases after.

A description of the medications used in conventional therapy in the course of the disease in all patients is presented in table III.

Two patients have not so far undergone the endoscopic follow-up after the establishment of the diagnosis of CD in the upper digestive tract (cases 5, 7). In the second, third and sixth case, in spite of the administered therapy, the following endoscopic features persisted: stricture of the duodenum, chronic inflammation of the mucosa, and ulceration of the pylorus, respectively.

\section{Discussion}

According to the literature, extra-intestinal location of $C D$ in the gastrointestinal tract is rare and generally concerns the oral cavity. The incidence rate of oral lesions is estimated at $4-20 \%[10,11]$. In a study performed in Ireland on children with CD, oral involvement was found in one third of examined patients [7]. Combining the clinical, endoscopic, histopathological and radiological findings is essential to achieve the diagnosis of $C D[8,12]$. However, the symptoms are related to the location of the disease. The lesions in the oral cavity observed in the first and the fourth described cases appeared long before other symptoms and the final diagnosis. Aphthous type lesions in the oral cavity, revealed in the physical examination, are common and can occur both in patients with CD and in the healthy population [7, 10]. The first trial to classify oral lesions specific for CD was made by Basu et al. in 1991. Only a few of the abnormalities described by them could be representative of $C D$, e.g. gingivitis and diffuse swelling of lips and cheeks [7, 8, 11]. The lesions can also appear as recurrent, linear in shape and aphthous type ulcerations, erythematous or cobblestone. In the study mentioned above, the most common lesion type revealed in physical examination was gingivitis [7]. The same lesions were observed in the first described case.

The diagnosis of oesophageal manifestation of CD has been very rare in recent years, although the reports from the latest studies reveal the incidence rate as 0.2$11 \%$. Probably this is related to routinely performed endoscopic evaluation [13, 14]. In 1970 Legree et al. examined 383 patients with CD, only 1 of whom (0.26\%) had diagnosed oesophageal manifestation. In contrast, D Hean revealed 14 cases of 124 examined patients (11.2\%) in 1994 [15]. The symptoms related to oesophageal manifestation are usually observed among patients with already diagnosed $C D[3,8]$. Isolated oesophageal manifestation of CD is unusual [16]. In such cases, without specific histological indicators and the absence of intestinal symptoms, the establishment of the diagnosis is very difficult. In our first subject the oesophageal lesions coexisted with typical segmental ulcerations in the colon. However, in the clinical view the oesophageal manifestation was predominant, with symptoms such as dysphagia, pain, heartburn or severe pain during swallowing due to the oesophageal lesions. Asymptomatic course of the disease is possible. The

Table III. Treatment of Crohn's disease

Tabela III. Leki stosowane w terapii choroby Leśniowskiego-Crohna

\begin{tabular}{|c|c|c|c|c|c|c|c|c|c|}
\hline & \multicolumn{7}{|c|}{ Conventional therapy } & \multicolumn{2}{|c|}{ Biological therapy } \\
\hline & \multirow[t]{2}{*}{ PPI } & \multirow[t]{2}{*}{ Mesalazine } & \multirow[t]{2}{*}{ Sulfasalazine } & \multirow[t]{2}{*}{ Azathioprine } & \multicolumn{3}{|c|}{ Steroids - periodically } & \multirow[t]{2}{*}{ Infliximab } & \multirow[t]{2}{*}{ Adalimumab } \\
\hline & & & & & Prednisone & $\begin{array}{c}\text { Methyl- } \\
\text { prednisolone }\end{array}$ & Budesonide & & \\
\hline 1. & + & & + & + & + & - & - & - & $\begin{array}{l}4 \text { months } \\
\text { (8 doses) }\end{array}$ \\
\hline 2. & + & + & - & + & + & - & + & (3 doses) & - \\
\hline 3. & + & - & + & + & + & + & - & 12 months & - \\
\hline 4. & + & + & + & + & + & - & - & 4 months & - \\
\hline 5. & - & + & + & + & + & - & - & - & - \\
\hline 6. & + & + & - & + & + & - & + & - & 24 months \\
\hline 7. & + & + & - & + & + & - & - & - & - \\
\hline
\end{tabular}


occurrence of stricture of the oesophagus or oesophageal-bronchial fistula, during the course of the disease, is probable. Then cough or pneumonia will be dominant symptom $[8,14]$. In the clinical view, dysphagia and weight loss were the most typical symptoms in the first case, whereas in the third heartburn and odynophagia were observed.

Endoscopy of the upper gastrointestinal tract can reveal the following lesions in the oesophageal region: irregular reddening or aphthous, or swollen folds of the mucous membrane, deep linear ulcerations located in the whole oesophageal mucous (which in fact is extremely rare) and strictures or fistulas $[9,17]$. Yekebas et al. reported a case of oesophageal perforation due to a stricture of the distal oesophagus as the primary manifestation of CD [17].

The appearance of stomach lesions in CD is uncommon and difficult to diagnose. It is considered that the presence of chronic non-healing ulcerations, despite the absence of histological features, may be due to CD [18]. According to some authors, if there is a suspicion of CD in the stomach or duodenum, the test for the presence of $H$. pylori should be performed, because it is one of the most important factors of chronic inflammation $[8,9]$. The most frequent endoscopic lesions, due to $C D$ in stomach, are located in the antrum and unusually in the corpus and fundus of the stomach $[9,19]$. Due to differential morphology of the lesions, it is difficult to distinguish them from lesions caused by other factors. They may present as reddening, cobblestone appearance of the mucosa, or erosions. The symptoms may mimic peptic ulcerations or gastric cancers [9]. The occurrence of focal or acute gastritis among patients with focal caecum inflammation can suggest the occurrence of $C D[20,21]$.

According to the data from the literature, the incidence of duodenal manifestation of CD is $0.5-4 \%[22,23]$. Lesions can be primary or secondary to involvement of the distal part of the gastrointestinal tract [24]. As reported, there is higher frequency of duodenal manifestation of $C D$ in the proximal part of the duodenum [8, 25], as was observed in both our cases. In contrast to peptic ulcers the ulceration due to CD is characterized by elongated shape, rarely circular or oval, or appears as serpiginous ulcers [8]. The occurrence of stenosis and deformity of the stomach and duodenum could be observed in the late stage of $C D$ and it can lead to gastrointestinal tract obstruction [9]. Duodenal fistulas are very rare [9], although El-Hajj II et al. reported a case of primary duodeno-colic fistula, surgically treated, due to CD [26].

According to the European Crohn's and Colitis Organisation (ECCO) statement of 2009, CD of the upper gastrointestinal tract may be treated with PPI and sometimes with systemic corticosteroids or, if neces- sary, with thiopurines or methotrexate. For severe or refractory disease, anti-TNF treatment is an alternative [27]. Local treatment is insufficient and regression of symptoms can be achieved only with intensification of regular therapy or initiation of biological treatment. In the last few years there have been more and more documents regarding effective use of infliximab in cases of CD in the upper digestive tract [13].

The most typical and useful histological sign of CD is sarcoid-like granuloma. However, the incidence of granuloma varies from $9 \%$ [19] to $20 \%$ [8], and it can be used to confirm the diagnosis only in a small percentage of cases. The other characteristic histopathological feature for $C D$ is the infiltration of lymphohistiocytic cells [6]. There were no granulomas found in our cases; only inflammatory process of the oesophageal, stomach and duodenal mucosa was revealed. According to many authors it could be related to the character of the disease itself. The inflammatory process in $C D$ is transmural, and can occur in every histological layer, whereas the nature of the endoscopic examination is superficial. That makes it difficult to obtain representative material for investigation $[6,8]$.

\section{Conclusions}

In conclusion, the role of upper endoscopic examination and the necessity of careful evaluation of the oral cavity for every patient with suspicion of CD should be pointed out. On the other hand, the diagnosis of CD should be taken into consideration for every patient with chronic inflammatory lesions, particularly in the oral cavity. These changes could be associated with asymptomatic lesions of CD in distal segments of the gastrointestinal tract. In our material in all subjects we identified coexistence of lesions in the upper digestive tract and the intestine. The results of biological therapy for the cases with manifestations in the upper gastrointestinal tract are comparable to the results of therapy of intestinal CD [13]. Therefore, biological therapy may be considered as an effective treatment for CD cases with involvement of the upper gastrointestinal tract [27].

\section{References}

1. Crohn BB, Ginzberg L, Oppenheimer GD. Regional Ileitis, a pathologic and clinical entity. JAMA 1932; 99: 1323-8.

2. Hildebrand H, Finkel Y, Grahnquist L, et al. Changing pattern of paediatric inflammatory bowel disease in northern Stockholm 1990-2001. Gut 2003; 52: 1432-4.

3. Kaplan KM, Prahalad S. Crohn disease of the esophagus in an adolescent. J Adolesc Health 1997; 21: 50-3.

4. Ardizzone S, Puttini PS, Cassinotti A, et al. Extraintestinal manifestations of inflammatory bowel disease. Dig Liver Dis 2008; 40: S253-9. 
5. Scully C, Cochran KM, Russell RI, et al. Crohn's disease of the mouth: an indicator of intestinal involvement. Gut 1982; 23: 198-201.

6. Basu MK, Asquith P, Thomson RA, et al. Oral manifestation of Crohn's disease. Gut 1975; 16: 249-54.

7. Harty S, Fleming P, Rowland M, et al. A Prospective Study of Oral Manifestation of Crohn's Disease. Clin Gastroenterol Hepatol 2005; 3: 886-91.

8. Wagtmans MJ, Van Hogezand RA, Griffioen G, et al. Crohn's disease of upper gastrointestinal track. Neth J Med 1997; 50: S2-S7.

9. van Hogezand RA, Witte AM, A. Veenendall RA, et al. Proximal Crohn's disease: Review of the Clinicopathologic Features and Therapy. Inflamm Bowel Dis 2001; 7: 328-37.

10. Paradowska A. Oral mucosa at Crohn's disease. Polish Gastroenterology 2008; 15: 309-11.

11. Mach T, Szczeklik K, Garlicka M, et al. Oral ulceration in patient with active Crohn's disease. Gastroenetrology Review 2007; 2: 210-3.

12. Feagans J, Victor D, Joshi V. Crohn disease of the esophagus: a review of the literature. South Med J 2008; 101: 927-30.

13. Turner D, Griffiths AM. Esophageal, gastric, and duodenal manifestations of IBD and the role of upper endoscopy in IBD diagnosis. Curr Gastroenetrol Rep 2007; 6: 475-8.

14. Ohta M, Konno H, Kamiya K, et al. Crohn's disease of the esophagus: report of a case. Surg Today 2000; 30: 262-7.

15. D'Haens G, Rutgeerts P, Geboes K, Vantrappen G. The natural history of esophageal Crohn's disease: three patterns of evolution. Gastrointest Endosc 1994; 40: 296-300.

16. Gasiorowska J, Czerwionka-Szaflarska M, Mierzwa G. Changes in the oesophagus in a 17-year-old girl with Crohn's disease. Gastroenterology Review 2008; 3: 108-11.

17. Yekebas E, Busch Ch, Soehendra N, et al. Boerhaave. Mimicking esophageal perforation with subsequent esophagobronchial fistula formation as the primary manifestation of Crohn's disease. Dig Surg 2000; 17: 631-3.

18. Bala G, Gasiorowska J, Czerwionka-Szaflarska M, et al. Spread changes in gastrointestinal tract in 17-years old boy with Crohn's disease. Gastroenterologia, Hepatologia i Żywienie Dziecka 2007; 9: 205-7.

19. Akbulut S, Rakuz B, Koseoglu T, et al. Crohn's disease with isolated esophagus and gastric involvement. Turk J Gastroenetrol 2004; 15: 196-200.

20. Petrolla AA, Katz JA, Xin W. The clinical significance of focal enhanced gastritis in adults with isolated ileitis of the terminal ileum. J Gastroenterol 2008 43: 524-30.

21. Assche Van G, Dignass A, Panes J, et al. The second European evidence-based Consensus on the diagnosis and management of Crohn's disease: Definitions and diagnosis. J Crohns Colitis 2010; 4: 7-27.

22. Shapiro M, Greenstein AJ, Byrn J, et al. Surgical management and outcomes of patients with duodenal Crohn's disease. J Am Coll Surg 2008; 207: 36-42.

23. Lukovich P, Papp A, Fuszek P, et al. Crohn's disease of the duodenum. Clinical signs, diagnosis, conservative and surgical treatment. Orv Hetil 2008; 16: 505-8.

24. Kimmins MH, Billingham RP. Duodenal Crohn's disease. Tech Coloproctol 2001; 5: 9-12.
25. Migaczewski M, Rembiasz K, Biesiada G, et al. Gastric Crohn's disease as a cause of gastrointestinal bleeding after gastrostroscopy-diagnostic difficulties. Przegl Lek 2006; 63: 698-700.

26. El-Hajj II, Abdul-Baki H, El-Zahabi LM, et al. Primary coloduodenal fistula in Crohn's disease. Dig Dis Sci 2007; 52: 59-6.

27. Dignass A, Assche Van G, Lindsay JO, et al. The second European evidence-based Consensus on the diagnosis and management of Crohn's disease: Current management. J Crohns Colitis 2010; 4: 28-62. 